\title{
SISTEM PENUNJANG KEPUTUSAN MULTI KRITERIA UNTUK PENGEMBANGAN AGROINDUSTRI KOPI GAYO MENGGUNAKAN PENDEKATAN FUZZY-ECKENRODE DAN FUZZY-TOPSIS
}

\author{
A MULTI-CRITERIA DECISION SUPPORT SYSTEM FOR THE DEVELOPMENT OF \\ GAYO COFFEE AGROINDUSTRY BY USING FUZZY-ECKENRODE AND \\ FUZZY-TOPSIS APPROACHES
}

\author{
Rahmat Fadhil $^{1)^{*}}$, M. Syamsul Maarif ${ }^{2)}$, Tajuddin Bantacut ${ }^{3)}$, Aji Hermawan ${ }^{2)}$ \\ ${ }^{1)}$ Program Studi Teknik Pertanian, Universitas Syiah Kuala, Darussalam 23111, Banda Aceh, Indonesia \\ *E-mail: rahmat.fadhil@unsyiah.ac.id, \\ ${ }^{2}$ Sekolah Bisnis, Institut Pertanian Bogor, Indonesia \\ ${ }^{3)}$ Departemen Teknologi Industri Pertanian, Fakultas Teknologi Pertanian, Institut Pertanian Bogor \\ Kampus IPB Dramaga 16002, Bogor, Indonesia \\ Makalah: Diterima 25 Agustus 2016; Diperbaiki 27 Januari 2017; Disetujui 5Februari 2017
}

\begin{abstract}
In multi-criteria decision making, accuracy in weighting for the determination of the various alternatives available criteria is always taken into account. The decision makers always face difficult choices in selecting options available. Hence, expert opinions are required as part of the decision making process. This study aimed to formulate a multi-criteria decision-making strategies and to propose priorities within Gayo coffee agroindustry development. A total of ten experts were involved to select various alternatives based on certain criteria that have been set. Weighting data analysis of the expert assessment conducted by Fuzzy-Eckenrode, whereas Fuzzy-Topsis method was used to determine alternative for Gayo coffee agroindustry development. This study found that Fuzzy-Eckenrode method was able to facilitate a good weighting result to determine a certain criterion in the consideration of Gayo coffee agroindustry development, and the application of the Fuzzy-Topsis approach provided a opportunity to find the main or the most ideal alternative of a Gayo coffee agroindustry development system. Based on the Fuzzy-Eckenrode approach, the highest weight founded was the assessment quality of various aspects that will be implemented. Meanwhile, form the Fuzzy-Topsis approach, it wasfound that institutional conduciveness as a priority in the Gayo coffee agroindustry development.
\end{abstract}

Keywords: decision-making systems, fuzzy-eckenrode, fuzzy-topsis, gayo coffee, multi-criteria

\section{ABSTRAK}

Pengambilan keputusan multi kriteria selalu mempertimbangkan akurasi dalam pembobotan untuk penentuan alternatif dari berbagai kriteria yang tersedia. Para pengambil kebijakan selalu akan dihadapkan pada pilihan-pilihan yang sulit untuk menentukan antara satu pilihan dengan pilihan lainnya. Pendapat para pakar diperlukan sebagai bagian dari pertimbangan terhadap suatu keputusan yang akan dilakukan. Penelitian ini bertujuan untuk merumuskan strategi pengambilan keputusan multi kriteria dan menyusun prioritas sebagai alternatif pengembangan agroindustri kopi Gayo dengan memperhatikan berbagai kriteria dalam pembangunan suatu agroindustri. Sebanyak sepuluh orang pakar diminta pendapatnya untuk memilihberbagai alternatif berdasarkan kriteria tertentu yang telah ditetapkan. Analisis data pembobotan penilaian para pakar dilakukan dengan metode Fuzzy-Eckenrode, sedangkan penentuan alternatif pengembangan agroindustri kopi Gayo menggunakan metode Fuzzy-Topsis. Hasil penelitian menunjukkan bahwa metode Fuzzy-Eckenrode mampu memberikan pembobotan secara baik untuk menentukan suatu kriteria tertentu dalam pertimbangan pengembangan agroindustri kopi Gayo, dan melalui pendekatan Fuzzy-Topsis dapat menemukan alternatif utama atau paling ideal dari suatu sistem pengembangan agroindustri kopi Gayo yang akan dilakukan. Berdasarkan pendekatan Fuzzy-Eckenrode diperoleh penilaian bobot tertinggi adalah Kualitas dari berbagai aspek pembangunan agroindustri yang akan dilakukan, sedangkan dengan pendekatan Fuzzy-Topsis diperoleh alternatif pengembangan agroindustri kopi Gayo yang harus lebih diutamakan adalah pada aspek kondusifitas kelembagaan.

Kata kunci: agroindustri, fuzzy-eckenrode, fuzzy-topsis,kopi Gayo, sistem pengambilan keputusan

\section{PENDAHULUAN}

Agroindustri kopi Gayo merupakan usaha yang sangat strategis bagi peningkatan perekonomian masyarakat produsen kopi di Propinsi Aceh. Austin (1992) mengemukakan bahwa agroindustri merupakan pilar strategis sebagai penggerak perekonomian suatu negara. Paling tidak terdapat empat hal yang melatarbelakanginya. Pertama, agroindustri merupakan jalan keluar bagi produk pertanian, ini berarti bahwa produk pertanian memerlukan pengolahan sampai pada level tertentu 
sehingga dapat menghasilkan nilai tambah. Kedua, agroindustri merupakan faktor penunjang utama sektor manufaktur yang berarti bahwa sumber daya pertanian sangat diperlukan pada tahap awal industrialisasi dan agroindustri, sehingga dapat menciptakan lapangan kerja, meningkatkan produksi, pemasaran dan pengembangan lembaga keuangan serta jasa. Ketiga, agroindustri memiliki andil dalam meningkatkan devisa negara, artinya produk pertanian mempunyai permintaan di pasar dunia, baik dalam bentuk bahan baku setengah jadi, maupun produk yang sudah jadi. Keempat, agroindustri mempunyai dimensi nutrisi, ini bermakna bahwa agroindustri dapat menjadi pemasok kebutuhan gizi masyarakat dan pemenuhan kebutuhan pangan secara nasional.

Kopi Gayo merupakan salah satu kopi specialty Indonesia dengan cita rasa yang khas sehingga telah mendapatkan sertifikasi Indeks Geografis sebagai kopi dengan nilai harga jual tertinggi di dunia (Herdyanti, 2013; Saputra, 2012). Kopi Gayo diproduksi di Dataran Tinggi GayoPropinsi Aceh, khususnya di Kabupaten Bener Meriah dan Kabupaten Aceh Tengah pada ketinggian 950-1450 meter diatas permukaan laut (Hulupi et al.,2013; Ditjenbun, 2011). Produktivitas kopi di daerah ini mencapai 700 sampai $800 \mathrm{~kg} / \mathrm{ha}$ dan seluruh lahan kopi diusahakan oleh perkebunan rakyat (Disbun Aceh, 2013). Secara nasional Kopi Gayo telah turut menyumbang 28,23\% dari total produksi kopi secara nasional (Kementan, 2013; Salima et al., 2012).

Dalam konsep pembangunan agroindustri, Austin (1992), Brown (1994) dan Nasution (2012) menyebutkan bahwa terdapat enam permasalahan utama, yaitu (1) kualitas sumber daya manusia, (2) kondusifitas kelembagaan, (3) sumber daya biofisik, meliputi air, lahan, lingkungan, produksi, kualitas, kuantitas dan bahan baku, (4) aplikasi teknologi, (5) akses pasar, dan (6) sistem pendukung lainnya yaitu kebijakan, investasi, infrastruktur, modal, status kepemilikan dan lainnya. Berdasarkan permasalahan tersebut, maka setiap pembangunan dan pengembangan agroindustri perlu memperhatikan ke enam aspek ini.

Di antara bebagai pendekatan untuk merancang sistem pengambilan keputusan dalam pengembangan agroindustri adalah melalui suatu pendekatan sistem pakar. Sistem pakar merupakan cara sistematis yang diterapkan dalam pengambilan keputusan berdasarkan pengetahuan yang dimiliki seseorang dengan kompetensi pendidikan atau pengalaman tertentu atas suatu permasalahan yang hendak diselesaikan. Dalam penelitian ini pendekatan sistem pakar menggunakan suatu metode pengambilan keputusan dengan teknik FuzzyEckenrodedan Fuzzy-Topsis(Technique for Order Performance by Similarity to Ideal Solution). Tujuan penelitian ini adalah untuk merumuskan strategi pengambilan keputusan multi kriteriadan menyusun prioritas sebagai alternatif pengembangan agroindustri kopi Gayo.

\section{METODE PENELITIAN}

\section{Kerangka Pemikiran}

Pengembangan agroindustri kopi Gayo senantiasa mempertimbangkan berbagai keadaan yang melingkupinya. Keadaan ini menurut para pakar adalah sebagai berikut: (1) kualitas, (2) kebijakan, (3) standarisasi, (4) konflik sosial, dan (5) gangguan keamanan. penjelasan lengkap tentang kriteria yang menjadi pertimbangan dalam pengembangan agroindustri kopi Gayo adalah seperti pada Tabel 1 .

Tabel 1. Kriteria Pengembangan Agroindustri Kopi

\begin{tabular}{llll}
\multicolumn{3}{c}{ Gayo } & \\
\hline No & Kriteria & Pertimbangan \\
\hline 1 & Kualitas & $\begin{array}{l}\text { Memenuhi kriteria mutu } \\
\text { Kebijakan }\end{array}$ & $\begin{array}{l}\text { Aturan yang merupakan } \\
\text { kebijakan } \\
\text { daerah } \\
\text { pemerintah }\end{array}$ \\
3 & Standarisasi & $\begin{array}{l}\text { Memenuhi standar yang } \\
\text { dipersyaratkan } \\
\text { Antar masyarakat baik } \\
\text { karena kesenjangan sosial } \\
\text { maupun yang disebabkan } \\
\text { persaingan usaha } \\
\text { Dipengaruhi oleh keadaan } \\
\text { politik dan pembangunan }\end{array}$ \\
& Konflik & Gasial & Keamananan
\end{tabular}

Adapun kerangka pemikiran penelitian ini melalui empat tahapan, yaitu tujuan, analisis, metode dan hasil yangdijadikan rekomendasi bagi para pengambil kebijakan dalam sistem pengambilan keputusan (Gambar 1). Kriteria yang menjadi pertimbangan dalam pembangunan agroindustri, meliputi:

- Kualitas (KU)

- $\quad$ Kebijakan (KB)

- Standarisasi (SD)

- Konflik Sosial (KS)

- Gangguan Keamanan (GK)

Sedangkan alternatif pengembangan agroindustri meliputi enam aspek, yaitu:

- Sumber Daya Manusia (SDM)

- Kondusifitas Kelembagaan (KKL)

- Sumber Daya Biofisik (SDB)

- Aplikasi Teknologi (ATN)

- Akses Pasar (APS)

- $\quad$ Sistem Pendukung (SPD)

Pada penelitian ini, penentuan bobot untuk menemukan kriteria yang paling penting berdasarkan pendapat para pakar dilakukan melalui metode Fuzzy-Eckenrode. 


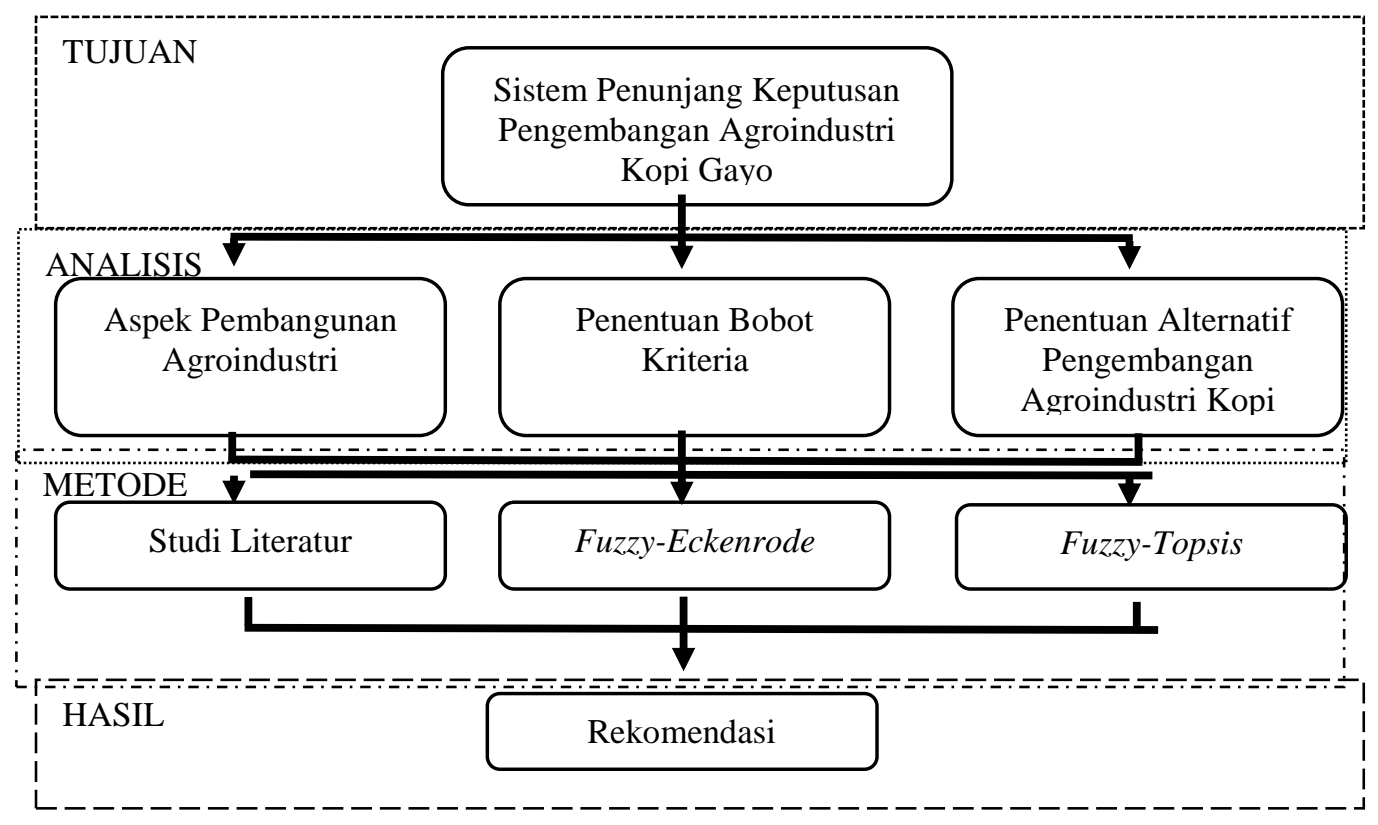

Gambar 1. Kerangka pemikiran penelitian

Kriteria ini secara umum terbadi dua, yaitu kriteria yang bermakna positif (seperti kualitas, kebijakan, dan standarisasi) dan kriteria yang bermakna negatif (seperti konflik sosial dan gangguan keamanan). Kriteria positif sangat diharapkan dalam suatu sistem penilaian dengan nilai setinggi-tingginya, sedangkan nilai negatif adalah serendah-rendahnya. Jadi untuk menilai sesuatu kriteria positif dan negatif perlu memahami karekteristik kecendrungan data yang diharapkan.

Hasil pembobotoan kriteria dengan pendekatan Fuzzy-Eckenrode dapat dipakai untuk analisis lebih lanjut terhadap berbagai alternatif strategi pengembangan agroindustri kopi Gayo melalui metode Fuzzy-Topsis. Metode Fuzzy-Topsis dilakukan untuk menentukan alternatif yang paling utama dari berbagai alternatif yang hendak dicapai dalam pengembangan agroindustri kopi Gayo. Hasil yang diharapkan akan semakin memudahkan para pengambil kebijakan untuk memutuskan langkahlangkah strategis yang akan diimplementasikan.

\section{Permodelan Sistem Fuzzy-Eckenrode}

Menurut Maarif dan Tanjung (2003) langkah-langkah dalam metode perhitungan bobot Eckenrode adalah responden diminta untuk melakukan perankingan (misalnya ranking dari R1 sampai dengan $\mathrm{Rn}$, dimana $\mathrm{n}$ ranking, $\mathrm{j}=1,2,3$, ..., $\mathrm{n}$; ranking ke $\mathrm{j}=\mathrm{R}_{\mathrm{j}}$ ) untuk setiap kriteria (kriteria ke $\mathrm{i}$, dinotasikan dengan $\mathrm{Ki}$, yang terdapat sebanyak $\mathrm{n}$ kriteria, $\mathrm{i}=1,2,3, \ldots ., \mathrm{n})$, sehingga diperoleh data seperti pada Tabel 2. Kemudian berdasarkan $P_{i j}$ dan $\mathrm{Rn}-\mathrm{j}$, dilakukan penghitungan Ni:

$$
N_{i}=\Gamma_{j=1} P_{r i j} \times R_{n-j}, j=1,2,3, \ldots \ldots, n \quad \ldots \ldots \ldots . .
$$

Total Nilai $=\Gamma_{\mathrm{i}=1} \mathrm{~N}_{\mathrm{i}}, \mathrm{i}=1,2,3, \ldots \ldots, \mathrm{n}$

Selanjutnya dilakukan penghitungan bobot kriteria Bi (yaitu B1, B2, B3,....., Bn), dimana $\mathrm{i}=1,2$, $3, \ldots, \mathrm{n}$, dengan menggunakan rumus:

$\mathrm{B}_{\mathrm{i}}=\left(\mathrm{N}_{\mathrm{i}} /\right.$ Total Nilai $)$

Untuk mengetahui tingkat kepentingan pada masingmasing Sub-Kriteria dalam suatu kriteria, responden juga diminta untuk meranking setiap Sub-Kriteria dalam suatu kriteria. Kemudian dengan prosedur yang sama dihitung juga bobot masing-masing SubKriteria dalam suatu kriteria $\left(\mathrm{B}_{\mathrm{li}}\right.$, bobot Sub-Kriteria 1 dalam Kriteria i). Dengan demikian, diperoleh Bobot Tertimbang (BT) dari Sub-Kriteria 1 dalam Kriteria i, yaitu $\mathrm{BT}_{1}=\mathrm{B}_{\text {li }} \times \mathrm{B}_{\mathrm{i}}$. Selanjutnya, untuk mengetahui nilai pada masing-masing kriteria, responden diminta untuk menilai dari masingmasing Sub-Kriteria pada masing-masing Kriteria.

Penilaian masing-masing Sub-Kriteria dihitung dengan menggunakan rumus rata-rata geometrik dari hasil penilaian dari seluruh narasumber dikalikan dengan Bobot Tertimbang dari masing-masing Sub-Kriteria tersebut. Kemudian pada masing-masing kriteria (K1 sampai K5) dihitung dengan menjumlahkan hasil dari seluruh nilai dari Sub-Kriteria-Sub-Kriteria yang terdapat pada setiap Kriteria.

Untuk memberikan penilaian pembobotan oleh para pakar digunakan metode Fuzzy-Eckenrode dengan preferensi nilai seperti Tabel 3.

\section{Permodelan Sistem Fuzzy-Topsis}

Prosedur analisis dengan menggunakan metode Fuzzy-Topsis adalah sebagai berikut (Rouyendegh dan Saputro, 2014): 
Tabel 2. Perhitungan Bobot Kriteria Metode Eckenrode

\begin{tabular}{|c|c|c|c|c|c|c|c|c|}
\hline \multirow{2}{*}{ Kriteria } & \multicolumn{6}{|c|}{ Ranking } & \multirow{2}{*}{ Nilai } & \multirow[t]{2}{*}{ Bobot } \\
\hline & $\mathbf{R}_{1}$ & $\mathbf{R}_{2}$ & $\ldots . .$. & $\mathbf{R}_{\mathbf{j}}$ & ....... & $\mathbf{R}_{\mathbf{n}}$ & & \\
\hline $\mathrm{K}_{1}$ & $\mathrm{P}_{11}$ & $\mathrm{P}_{12}$ & ....... & & & $P_{1 n}$ & $\mathrm{~N}_{1}$ & $\mathrm{~B}_{1}$ \\
\hline $\mathrm{K}_{2}$ & $\mathrm{P}_{21}$ & $\mathrm{P}_{22}$ & ...... & & & $\mathrm{P}_{2 \mathrm{n}}$ & $\mathrm{N}_{2}$ & $\mathrm{~B}_{2}$ \\
\hline$\ldots \ldots$ & $\ldots \ldots$ & $\ldots \ldots$ & $\ldots \ldots$ & & & $\ldots \ldots$ & $\ldots .$. & $\ldots \ldots$ \\
\hline $\mathrm{K}_{\mathrm{i}}$ & & & & $P_{i j}$ & & & & \\
\hline $\mathrm{K}_{\mathrm{n}}$ & $\mathrm{P}_{\mathrm{n} 1}$ & $\mathrm{P}_{\mathrm{n} 2}$ & $\ldots \ldots$. & & & $\mathrm{P}_{\mathrm{mn}}$ & $\mathrm{N}_{\mathrm{n}}$ & $\mathrm{B}_{\mathrm{n}}$ \\
\hline Faktor Pengali & $\mathrm{R}_{\mathrm{n}-1}$ & $R_{n-2}$ & $\ldots \ldots$ & $R_{n-j}$ & & $R_{n-n}$ & Total Nilai & 1,00 \\
\hline
\end{tabular}

Keterangan:

$\mathrm{Rj} \quad=$ Urutan ranking ke $\mathrm{j}, \mathrm{j}=1,2,3, \ldots \ldots, \mathrm{n}$.

$\mathrm{Ki} \quad=$ Jenis kriteria ke $\mathrm{i}, \mathrm{i}=1,2,3, \ldots \ldots, \mathrm{n}$.

$\mathrm{Pij}=$ Jumlah responden yang memilih ranking ke $\mathrm{j}$, untuk kriteria ke $\mathrm{i}$

$\mathrm{Rn}-\mathrm{j}=$ Faktor pengali ke $\mathrm{j}$, yang diperoleh dari pengurangan banyaknya kriteria atau banyaknya rangking (yaitu $\mathrm{n}$ ) dengan urutan rangking pada kolom tersebut. Misal ada 5 kriteria maka faktor pengali pada kolom rangking ke 3 (misal $\mathrm{j}=3$ ) adalah $n-\mathrm{j}=5-3=2$.

$\mathrm{Bi}=$ Bobot kriteria ke $\mathrm{i}$

Tabel 3. Skala Perbandingan Pembobotan Antar Kriteria Metode Fuzzy-Eckenrode

\begin{tabular}{|c|c|c|}
\hline Skala & Keterangan & $\begin{array}{c}\text { Fungsi Keanggotaan } \\
\text { TFN }\end{array}$ \\
\hline$\sim 1$ & Sangat Tidak & (2) \\
\hline $\begin{array}{l}1 \\
\sim 2\end{array}$ & Penting & $\begin{array}{l}1,1,2 \\
123\end{array}$ \\
\hline$\sim 2$ & Kurang Penting & $\begin{array}{l}1,2,3 \\
2,3,4\end{array}$ \\
\hline$\sim$ & Netral & $\begin{array}{l}2,3,4 \\
3,4,5\end{array}$ \\
\hline $\begin{array}{r}4 \\
\sim 5\end{array}$ & $\begin{array}{l}\text { Penting } \\
\text { Sangat Penting }\end{array}$ & $\begin{array}{l}5,4,5, \\
4,5,5\end{array}$ \\
\hline
\end{tabular}

1. Merangking fuzzy dari setiap keputusan yang dibuat, Dk; $(\mathrm{k}=1,2,3, \ldots . \mathrm{K})$ dapat direpresentasikan sebagai angka segitiga fuzzy ${ }^{2} \mathrm{Rk} ; \quad(\mathrm{k}=1,2,3, \ldots, \mathrm{K})$ dengan fungsi keanggotaan $\mu^{\sim} \mathrm{R}(\mathrm{x})$.

2. Menghasilkan alternatif yang layak, menentukan kriteria evaluasi, dan pengaturan kelompok pembuat keputusan. Diasumsikan bahwa ada m alternatif, $\mathrm{n}$ kriteria evaluasi, dan keputusan $\mathrm{k}$.

3. Memilih variabel linguistik yang tepat dengan bobot kepentingan kriteria $=\left(\widetilde{w}_{j}=l_{i j}, m_{i j}, u_{i j}\right)$ dan peringkat linguistik alternatif terhadap kriteria $\left(\tilde{x}_{i j}\right)$ dalam Triangular Fuzzy Number (TFN).

4. Melakukan agregasi bobot dari setiap kriteria untuk mendapatkan agregat bobot fuzzy $\left(\widetilde{w}_{j}\right)$ pada kriteria $C_{j}$ dan menentukan nilai agregat fuzzy dari alternatif $A_{i}$ pada setiap kriteria $C_{j}$.

$\tilde{x}_{i j}=\frac{1}{k}\left[\tilde{x}_{i j}^{1}+\tilde{x}_{i j}^{2}+\ldots .+\tilde{x}_{i j}^{k}\right] \quad \mathrm{i}=1,2, \ldots, \mathrm{m}$;

dan $\mathrm{j}=1,2, \ldots ., \mathrm{n}$

$\widetilde{w}_{j}=\frac{1}{k}\left[\widetilde{w}_{j}^{1}+\widetilde{w}_{j}^{2}+\ldots .+w_{j}^{k}\right] \quad \mathrm{j}=1,2, \ldots, \mathrm{n} .(5)$

5. Membangun matrik keputusan fuzzy

$$
\begin{aligned}
& \begin{array}{llll}
C_{1} & C_{2} & \ldots & C_{n}
\end{array}
\end{aligned}
$$

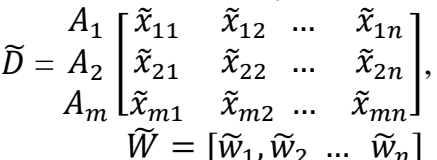

$$
\mathrm{i}=1,2, \ldots, \mathrm{m} ; \text { dan } \mathrm{j}=1,2, \ldots ., \mathrm{n}
$$

6. Melakukan normalisasi matrik keputusan, dimana:

$\tilde{R}=\left[\tilde{r}_{i j}\right]_{m x n} \mathrm{i}=1,2, \ldots, \mathrm{m} ;$ dan $\mathrm{j}=1,2, \ldots ., \mathrm{n}$.

Untuk menghitung $\left[\tilde{r}_{i j}\right]_{m x n}$ dapat dilakukan dengan :

$\tilde{r}_{i j}=\left(\frac{l_{i j}}{U_{j}^{*}}, \frac{m_{i j}}{U_{j}^{*}}, \frac{u_{i j}}{U_{j}^{*}},\right)$ dimana $U_{j}^{*}=\max u_{i j}$

7. Menentukan normalisasi bobot dari matrik keputusan fuzzy. Berdasarkan kepentingan berbeda dari setiap kriteria, maka dapat disusun keputusan fuzzy matrik normalisasi tertimbang : $\tilde{V}=\left[\tilde{v}_{i j}\right]_{m x n}$ dengan, $\mathrm{i}=1,2, \ldots, \mathrm{m} ; \operatorname{dan} \mathrm{j}=1$,

$2, \ldots ., \mathrm{n}$

dimana :

$\tilde{v}_{i j}=\tilde{r}_{i j} \otimes \widetilde{w}_{i j}$ dengan, $\mathrm{i}=1,2, \ldots, \mathrm{m} ;$ dan $\mathrm{j}=1$,

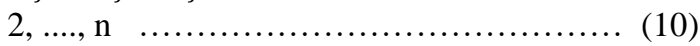

8. Menentukan solusi positif yang ideal fuzzy (FPIS) S+ dan solusi negatif-ideal fuzzy (FNIS) S-, yaitu:

$$
\begin{aligned}
& S^{+}=\left(\tilde{v}_{1}^{+}, \tilde{v}_{2}^{+}, \ldots, \tilde{v}_{n}^{+}\right) \\
& S^{-}=\left(\tilde{v}_{1}^{-}, \tilde{v}_{2}^{-}, \ldots, \tilde{v}_{n}^{-}\right)
\end{aligned}
$$

Dimana : $\tilde{v}_{j}^{+}=\max \left\{v_{i j 3}\right\}$ dan $\tilde{v}_{j}^{-}=\min \left\{v_{i j 1}\right\}$ dengan $\tilde{v}_{j}$ merupakan bobot normalisasi TFN

9. Menghitung jarak nilai antara setiap nilai alternatif dengan nilai FPIS(fuzzy positive ideal solution) dan FNIS (fuzzy negative ideal solution), melalui persamaan:

$$
\begin{gathered}
d\left(A_{1}, A_{2}\right)=\sqrt{\frac{1}{3}\left[\left(l_{1}-l_{2}\right)^{2}\right.}+\left(m_{1}-m l_{2}\right)^{2}+ \\
\left(u-u_{2}\right)^{2} \ldots \ldots \ldots \ldots \ldots \ldots \ldots \ldots \ldots \ldots \ldots \ldots \ldots \ldots \ldots \ldots \ldots \ldots \ldots \ldots \ldots \ldots \ldots \ldots \\
d_{1}^{+}=\sum_{j=1}^{n} d\left(\tilde{v}_{i j}, \tilde{v}_{j}^{+}\right), i=1,2, \ldots, m \ldots \ldots \ldots \ldots \\
d_{1}^{-}=\sum_{j=1}^{n} d\left(\tilde{v}_{i j}, \tilde{v}_{j}^{-}\right), i=1,2, \ldots, m \ldots \ldots \ldots \ldots
\end{gathered}
$$


10. Menghitung nilai koefisien kedekatan antar jarak (CCi) dan rangking sesuai dengan nilai koefisien yang diperoleh dengan persamaan:

$$
C C_{i}=\frac{d_{i}^{-}}{d_{i}^{+}+d_{i}^{-}}, i=1,2, \ldots, m
$$

Untuk memberikan penilaian pada setiap alternatif oleh para pakar dengan menggunakan metode FuzzyTopsis dengan preferensi nilai seperti Tabel 4.

Tabel 4. Skala perbandingan penentuan alternatif metode fuzzy-Topsis

\begin{tabular}{|c|c|c|}
\hline Skala & & Linguistik TFN \\
\hline Sangat Tidak Penting & (STP) & $0,0,1$ \\
\hline Tidak Penting & (TP) & $0,1,3$ \\
\hline Kurang Penting & (KP) & $1,3,5$ \\
\hline Netral & $(\mathrm{N})$ & $3,5,7$ \\
\hline Agak Penting & (AP) & $5,7,9$ \\
\hline Penting & (P) & $7,9,9$ \\
\hline Sangat Penting & (SP) & $9,9,10$ \\
\hline
\end{tabular}

\section{Penentuan Pakar}

Para pakar yang diminta pendapatnya dalam penelitian ini adalah sebanyak sepuluh orang. Pakar merupakan orang-orang yang dianggap memiliki kecakapan, latar belakang yang sesuai dan pengetahuan yang mendalam berkaitan dengan objek kajian yaitu pengembangan agroindustri kopi Gayo. Pengumpulan data dilakukan melalui wawancara, penyebaran kuisioner, pengamatan langsung dan sintesa data di lapangan. Para pakar yang berkompeten untuk memberikan keputusan memiliki kepakaran berdasarkan pendidikan formal pada bidang yang di teliti, berdasarkan pengalaman dan riwayat pekerjaan, serta praktisi di bidang yang terkait dengan kopi Gayo. Para pakar yang dimaksud dalam penelitian ini adalah dari Dinas Perkebunan dan Kehutanan Kabupaten Aceh Tengah, dosen Universitas Gajah Putih di Takengon, petani kopi Gayo, pedagang pengumpul, pengusaha kopi Gayo, dan pemerhati Kopi Gayo.

\section{Penentuan Bobot Kriteria Pengembangan Agroindustri}

Bobot kriteria yang diberikan para pakar dalam bentuk nilai fuzzy untuk menilai tingkat kepentingan antar kriteria adalah seperti pada Tabel 5.

Berdasarkan data penilaian pakar terhadap kriteria penentuan bobot kepentingan, maka dapat dijabarkan kedalam nilai batas bawah (low), tengah (medium) dan batas atas (upper) seperti terangkum pada Tabel 6.

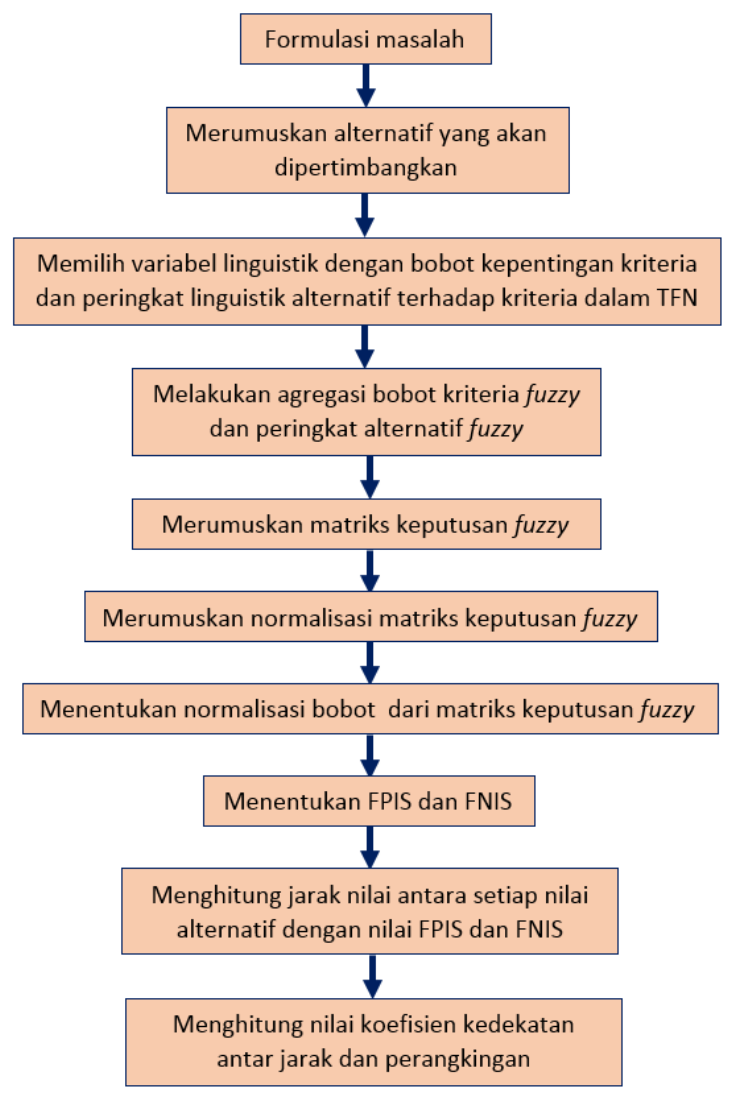

Gambar 2. Tahapan analisis metode Fuzzy-Topsis 
Tabel 5. Nilai pebobotan pakar pada kriteria metode fuzzy-Eckenrode

\begin{tabular}{llccccc}
\hline \multirow{2}{*}{ No } & \multirow{2}{*}{ Kriteria } & \multicolumn{5}{c}{ Urutan } \\
\cline { 3 - 7 } & & $\mathbf{1}$ & $\mathbf{2}$ & $\mathbf{3}$ & $\mathbf{4}$ & 5 \\
\hline 1 & Kualitas & 5 & $\sim 2$ & $\sim 1$ & $\sim 1$ & $\sim 1$ \\
2 & Kebijakan & $\sim 4$ & $\sim 2$ & $\sim 2$ & $\sim 1$ & $\sim 1$ \\
3 & Standarisasi & $\sim 2$ & $\sim 1$ & $\sim 4$ & $\sim 2$ & $\sim 1$ \\
4 & Konflik Sosial & $\sim 1$ & $\sim 2$ & $\sim 4$ & $\sim 2$ & $\sim 1$ \\
5 & Gangguan Keamanan & $\sim 4$ & $\sim 2$ & $\sim 1$ & $\sim 2$ & $\sim 1$ \\
\hline Nilai (Tkriteria-urutan) & 4 & 3 & 2 & 1 & 0 \\
\hline
\end{tabular}

Tabel 6. Nilai TFN pebobotan pakar pada kriteria metode Fuzzy-Eckenrode

\begin{tabular}{|c|c|c|c|c|c|c|c|c|c|c|c|c|c|c|c|c|c|c|}
\hline \multirow{2}{*}{ No } & \multirow{2}{*}{ Kriteria } & \multicolumn{3}{|c|}{1} & \multicolumn{3}{|c|}{2} & \multicolumn{3}{|c|}{3} & \multicolumn{3}{|c|}{4} & \multicolumn{3}{|c|}{5} & \multirow{2}{*}{ Nilai } & \multirow{2}{*}{ Bobot } \\
\hline & & 1 & $\mathbf{m}$ & $\mathbf{u}$ & l & $\mathbf{m}$ & $\mathbf{u}$ & 1 & $\mathbf{m}$ & $\mathbf{u}$ & 1 & $\mathbf{m}$ & $\mathbf{u}$ & 1 & $\mathbf{m}$ & $\mathbf{u}$ & & \\
\hline 1 & Kualitas & 4 & 5 & 5 & 1 & 2 & 3 & 1 & 1 & 2 & 1 & 1 & 2 & 1 & 1 & 2 & 86 & 0,228 \\
\hline 2 & Kebijakan & 3 & 4 & 5 & 1 & 2 & 3 & 1 & 2 & 3 & 1 & 1 & 2 & 1 & 1 & 2 & 82 & 0,217 \\
\hline 3 & Standarisasi & 1 & 2 & 3 & 1 & 1 & 2 & 3 & 4 & 5 & 1 & 2 & 3 & 1 & 1 & 2 & 66 & 0,175 \\
\hline 4 & Konflik Sosial & 1 & 1 & 2 & 1 & 2 & 3 & 3 & 4 & 5 & 1 & 2 & 3 & 1 & 1 & 2 & 64 & 0,169 \\
\hline 5 & $\begin{array}{l}\text { Gangguan } \\
\text { Keamanan }\end{array}$ & 3 & 4 & 5 & 1 & 2 & 3 & 1 & 1 & 2 & 1 & 2 & 3 & 1 & 1 & 2 & 80 & 0,212 \\
\hline & $\begin{array}{c}\text { Nilai } \\
\text { kriteria-urutan) }\end{array}$ & & 4 & & & 3 & & & 2 & & & 1 & & & 0 & & 378 & 1,000 \\
\hline
\end{tabular}

Selanjutnya dilakukan perhitungan nilai dan bobot untuk setiap kriteria, sehingga dapat digambarkan suatu diagram radar seperti Gambar 3. Berdasarkan penilaian pakar pada kriteria dengan metode Fuzzy-Eckenrode diperolehlah urutan dengan bobot kriteria tertinggi sampai yang paling rendah yaitu (1) kualitas $(0,228)$, (2) kebijakan $(0,217)$, (3) gangguan keamanan $(0,212)$, (4) Standarisasi $(0,175)$ dan (5) Konflik Sosial $(0,169)$.

Metode analisis pembobotan Eckenrode merupakan salah satu metode pembobotan yang digunakan untuk menentukan derajat kepentingan atau Bobot (B) dari setiap Kriteria (K) dan Sub Kriteria (SK) yang ditetapkan dalam pengambilan keputusan (Maarif dan Tanjung, 2003). Metode ini lebih sederhana dan efisien dalam menyelesaikan permasalahan dalam penentuan bobot kepentingan dalam suatu keputusan (Salam, 2014; Dadelo et al., 2012; Eckenrode, 1965). Penentuan bobot ini dinilai sangat penting karena akan mempengaruhi nilai total akhir dari setiap pilihan keputusan. Konsep yang digunakan dalam metode pembobotan ini adalah dengan melakukan perubahan urutan menjadi nilai dimana misalnya urutan 1 dengan tingkat (nilai) tertinggi dan urutan 5 dengan tingkat di terendah.

\section{Penentuan Prioritas Alternatif Pengembangan Agroindustri}

Pada tahap awal untuk menentukan prioritas alternatif pengembangan agroindustri kopi Gayo adalah dengan merangkumkan semua pendapat para pakar, dimana pendapat tersebut dipilih berdasarkan nilai modus (angka yang paling sering muncul dari populasi atau sampel) yang diberikan oleh pakar. Selanjutnya disusun matrik penilaian pakar terhadap alternatif seperti pada Tabel 7 .

Tabel 7. Matrik penilaian pakar terhadap alternatif

\begin{tabular}{lllllll}
\hline \multirow{2}{*}{ Kriteria } & \multicolumn{5}{c}{ Alternatif } \\
\cline { 2 - 6 } & $\begin{array}{l}\text { SD } \\
\text { M }\end{array}$ & KKL & SDB & ATN & APS & SPD \\
\hline KU & P & SP & SP & N & KP & N \\
KB & SP & SP & AP & AP & N & KP \\
SD & SP & P & P & P & AP & AP \\
KS & P & P & AP & N & AP & N \\
GK & AP & AP & P & AP & N & AP \\
\hline
\end{tabular}

Data penilaian pakar selanjutnya diubah ke dalam data linguistik TFN seperti disajikan pada Tabel 8. Berikutnya dirumuskan matrik bobot ternormalisasi pada setiap alternatif. Normalisasi nilai dapat dilakukan dengan menggunakan persamaan (7) dan secara detail pada persamaan (8). Adapun hasil normalisasi nilai TFN dapat dilihat pada Tabel 9.

Kemudian disusun matrik perkalian antara bobot kriteria dengan nilai normalisasi setiap alternatif. Proses ini dapat dilakukan dengan menggunakan persamaan (9) dan (10). Hasil perkalian matrik terangkum pada Tabel 10.

Tahap berikutnya menentukan nilai solusi ideal positif (FPIS) $\mathrm{S}^{+}$dan nilai solusi ideal negatif (FNIS) $\mathrm{S}^{-}$. Penentuan kedua nilai perlu memperhatikan karakteristik data yang ada. Untuk memperoleh kedua kelompok nilai ini dapat dilakukan dengan persamaan (11) dan (12). Adapun nilai FPIS dan FNIS terangkum pada Tabel 11. 
Selanjutnya menghitung nilai jarak antara masing-masing nilai alternatif dengan nilai solusi ideal positif dan nilai solusi ideal negatif. Tahap ini dapat dilakukan dengan menggunakan persamaan

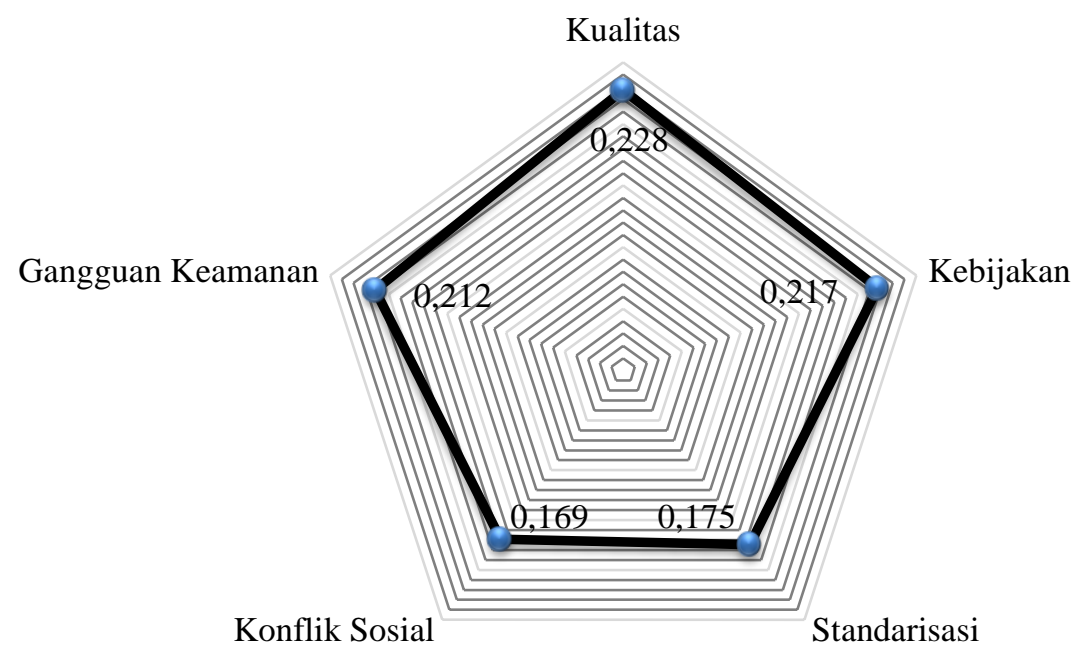

Gambar 3. Diagram radar bobot kriteria

Konflik Sosial

Standarisasi
(13), (14) dan (15). Hasil perhitungan jarak antar nilai alternatif terhadap solusi ideal positif dan negatif dapat dilihat pada Tabel 12 .

\begin{tabular}{ccccccc}
\hline \multirow{2}{*}{ Kriteria } & \multicolumn{7}{c}{ Alternatif } \\
\cline { 2 - 7 } & SDM & KKL & SDB & ATN & APS & SPD \\
\hline KU $(0,217,0,228,0,228)$ & $(7,9,9)$ & $(9,9,10)$ & $(9,9,10)$ & $(3,5,7)$ & $(1,3,5)$ & $(3,5,7)$ \\
KB $(0,212,0,217,0,228)$ & $(9,9,10)$ & $(9,9,10)$ & $(5,7,9)$ & $(5,7,9)$ & $(3,5,7)$ & $(1,3,5)$ \\
SD $(0,169,0,175,0,212)$ & $(9,9,10)$ & $(7,9,9)$ & $(7,9,9)$ & $(7,9,9)$ & $(5,7,9)$ & $(5,7,9)$ \\
KS $(0,169,0,169,0,175)$ & $(7,9,9)$ & $(7,9,9)$ & $(5,7,9)$ & $(3,5,7)$ & $(5,7,9)$ & $(3,5,7)$ \\
GK $(0,175,0,212,0,217)$ & $(5,7,9)$ & $(5,7,9)$ & $(7,9,9)$ & $(5,7,9)$ & $(3,5,7)$ & $(5,7,9)$ \\
\hline
\end{tabular}

Tabel 9.Matrik Normalisasi Skala TFN

\begin{tabular}{lllllll}
\hline \multirow{2}{*}{ Kriteria } & \multicolumn{7}{c}{ Alternatif } \\
\cline { 2 - 7 } & SDM & KKL & SDB & ATN & APS & SPD \\
\hline
\end{tabular}

$\mathrm{KU}(0,217,0,228,0,228)(0,70,0,90,0,90)(0,90,0,90,1,00)(0,90,0,90,1,00) \quad(0,30,0,50,0,70) \quad(0,10,0,30,0,50) \quad(0,30,0,50,0,70)$ $\mathrm{KB}(0,212,0,217,0,228)(0,90,0,90,1,00)(0,90,0,90,1,00)(0,50,0,70,0,90)(0,50,0,70,0,90)(0,30,0,50,0,70)(0,10,0,30,0,50)$ $\mathrm{SD}(0,169,0,175,0,212) \quad(0,90,0,90,1,00)(0,70,0,90,0,90)(0,70,0,90,0,90) \quad(0,70,0,90,0,90) \quad(0,50,0,70,0,90) \quad(0,50,0,70,0,90)$ KS $(0,169,0,169,0,175)(0,78,1,00,1,00) \quad(0,78,1,00,1,00)(0,56,0,78,1,00)(0,33,0,56,0,78) \quad(0,56,0,78,1,00) \quad(0,33,0,56,0,78)$ GK $(0,175,0,212,0,217)(0,56,0,78,1,00)(0,56,0,78,1,00)(0,78,1,00,1,00)(0,56,0,78,1,00)(0,33,0,56,0,78)(0,56,0,78,1,00)$

Tabel 10. Matrik perkalian bobot kriteria dan nilai normalisasi alternatif

\begin{tabular}{ccccccc}
\hline \multirow{2}{*}{ Kriteria } & SDM & KKL & SDB & ATN & APS & SPD \\
\cline { 2 - 6 } & & & & & \\
KU & $(0,15,0,20,0,20)$ & $(0,20,0,20,0,23)$ & $(0,20,0,20,0,23)$ & $(0,07,0,11,0,16)$ & $(0,02,0,07,0,11)$ & $(0,07,0,11,0,16)$ \\
KB & $(0,19,0,20,0,23)$ & $(0,19,0,20,0,23)$ & $(0,11,0,15,0,20)$ & $(0,11,0,15,0,20)$ & $(0,06,0,11,0,16)$ & $(0,02,0,07,0,11)$ \\
SD & $(0,15,0,16,0,21)$ & $(0,12,0,16,0,19)$ & $(0,12,0,16,0,19)$ & $(0,12,0,16,0,19)$ & $(0,08,0,12,0,19)$ & $(0,08,0,12,0,19)$ \\
KS & $(0,13,0,17,0,17)$ & $(0,13,0,17,0,17)$ & $(0,09,0,13,0,17)$ & $(0,06,0,09,0,14)$ & $(0,09,0,13,0,17)$ & $(0,06,0,09,0,14)$ \\
GK & $(0,10,0,16,0,22)$ & $(0,10,0,16,0,22)$ & $(0,14,0,21,0,22)$ & $(0,10,0,16,0,22)$ & $(0,06,0,12,0,17)$ & $(0,10,0,16,0,22)$ \\
& & & & & & \\
\hline
\end{tabular}

Tabel 11. Nilai solusi ideal positif dan solusi ideal negatif

\begin{tabular}{lll}
\hline Kriteria & S $(+)$ & $\mathbf{S}(-)$ \\
\hline KU & $(0,23,0,23,0,23)$ & $(0,02,0,02,0,02)$ \\
KB & $(0,23,0,23,0,23)$ & $(0,02,0,02,0,02)$ \\
SD & $(0,21,0,21,0,21)$ & $(0,08,0,08,0,08)$ \\
KS & $(0,06,0,06,0,06)$ & $(0,17,0,17,0,17)$ \\
GK & $(0,06,0,06,0,06)$ & $(0,22,0,22,0,22)$ \\
\hline
\end{tabular}


Tabel 12. Nilai jarak antara nilai kriteria dengan FPIS dan FNIS

\begin{tabular}{ccccccc}
\hline \multirow{2}{*}{ Kriteria } & \multicolumn{6}{c}{ FPIS $\left(\mathbf{d}^{+}\right)$} \\
\cline { 2 - 7 } & SDM & KKL & SDB & ATN & APS & SPD \\
\hline KU & 0,047 & 0,023 & 0,023 & 0,121 & 0,164 & 0,121 \\
KB & 0,028 & 0,028 & 0,084 & 0,084 & 0,123 & 0,165 \\
SD & 0,046 & 0,063 & 0,063 & 0,063 & 0,090 & 0,090 \\
KS & 0,104 & 0,104 & 0,084 & 0,051 & 0,084 & 0,051 \\
GK & 0,113 & 0,113 & 0,135 & 0,113 & 0,072 & 0,113 \\
& & & & & \\
\hline \multirow{2}{*}{$\mathrm{d}+$} & 0,339 & 0,331 & 0,389 & 0,432 & 0,534 & 0,540 \\
\hline
\end{tabular}

\begin{tabular}{ccccccc}
\hline \multirow{2}{*}{ Kriteria } & \multicolumn{6}{c}{ FNIS $\left(\mathbf{d}^{+}\right)$} \\
\cline { 2 - 6 } & SDM & KKL & SDB & ATN & APS & SPD \\
\hline KU & 0,167 & 0,188 & 0,188 & 0,099 & 0,060 & 0,099 \\
KB & 0,184 & 0,184 & 0,139 & 0,139 & 0,097 & 0,059 \\
SD & 0,093 & 0,077 & 0,077 & 0,077 & 0,065 & 0,065 \\
KS & 0,025 & 0,025 & 0,053 & 0,086 & 0,053 & 0,086 \\
GK & 0,076 & 0,076 & 0,047 & 0,076 & 0,112 & 0,076 \\
\hline d- & 0,545 & 0,549 & 0,503 & 0,475 & 0,386 & 0,384 \\
\hline
\end{tabular}

Untuk mengevaluasi nilai jarak kriteria dengan fuzzy positive ideal solution (FPIS) dan fuzzy negative ideal solution (FNIS) berdasarkan perbandingan dari $\mathrm{d}+$ dan $\mathrm{d}$ - menunjukkan aspek utama pengembangan agroindustri dalam diagram radar (Gambar 4.) Sebagai contoh, dapat dilihat bahwa Kondusifitas Kelembagaan (KKL) memiliki nilai d+ dan d-yang menunjukkan jarak terbesar dari ideal positif dan ideal negative.

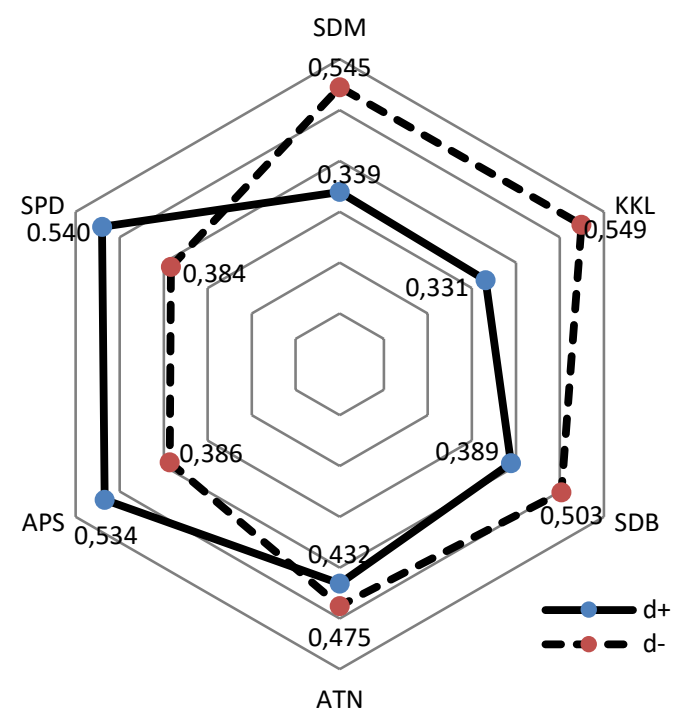

Gambar 4. Evaluasi d+ dan d-

Menurut Dashti et al. (2010) metode Topsis menggunakan prinsip bahwa alternatif yang terpilih harus mempunyai jarak terdekat dari solusi ideal positif dan terjauh dari solusi ideal negatif untuk menentukan kedekatan relatif dari suatu alternatif dengan solusi optimal. Solusi ideal positif didefinisikan sebagai jumlah dari seluruh nilai terbaik yang dapat dicapai untuk setiap atribut, sedangkan solusi ideal negatif terdiri dari seluruh nilai terburuk yang dicapai untuk setiap atribut. Topsis mempertimbangkan keduanya, jarak terhadap solusi ideal positif dan jarak terhadap solusi ideal negatif dengan mengambil kedekatan relatif terhadap solusi ideal positif.

Dalam banyak kondisi, data yang ada terkadang tidak memadai untuk permasalahan dalam kehidupan nyata karena penilaian manusia yang termasuk preferensi sering kabur atau kurang jelas dan tidak dapat memperkirakan preferensinya

dengan nilai numerik yang tepat. Ekspresi bahasa, misalnya rendah, sedang, tinggi, dan lain-lain dianggap sebagai representasi pembuat keputusan. Untuk itu diperlukan logika fuzzy dalam membuat keputusan pembuat preferensi yang terstruktur. Teori fuzzy membantu dalam konsep mengukur ketidakjelasan yang berkaitan dengan manusia yang bersifat subjektif. Dalam hal ini, fuzzy mampu membantu untuk memperbaiki kegagalan yang terjadi ketika hanya menggunakan metode Topsis saja (Ningrum et al., 2012).

Tahap akhir metode dari ini adalah menghitung nilai koefisien kedekatan (closeness coeficient - $\mathrm{CCi}$ ) masing-masing alternatif dengan menggunakan persamaan (16). Dari hasil perhitungan maka diperoleh ranking nilai dari yang terbesar hingga terkecil (Tabel 13). Nilai koefisien terbesar merupakan alternatif utama yang disarankan untuk dipilih atau diprioritaskan dibandingkan alternatif lainnya.

Tabel 13. Koefisien kedekatan dan rangking alternatif

\begin{tabular}{ccc}
\hline Alternatif & CCi & Rank \\
\hline SDM & 0,617 & 2 \\
KKL & 0,624 & 1 \\
SDB & 0,564 & 3 \\
ATN & 0,524 & 4 \\
APS & 0,420 & 5 \\
SPD & 0,415 & 6 \\
\hline
\end{tabular}

Berdasarkan nilai koefisien kedekatan (CCi), maka dapat disusun peringkat alternatif dari yang terbesar ke yang terkecil adalah (1) kondusifitas kelembagaan (KKL), (2) sumber daya manusia (SDM), (3) sumber daya biofisik (SDB), (4) aplikasi teknologi (ATN), (5) akses pasar (APS), dan (6) sistem pedukung (SPD) (Gambar 5).

Oleh karenanya, dari hasil analisis dengan pendekatan Fuzzy-Topsis pada langkah-langkah diatas, telah diperoleh suatu keputusan bahwa alternatif utama dan ideal menurut preferensi pakar adalah kodusifitas kelembagaan (KKL). Walaupun demikian dari analisis ini terlihat bahwa antara aspek kondusifitas kelembagaan (KKL) dengan aspek sumber daya manusia (SDM) memiliki nilai yang sangat dekat, sehingga ini menjadi pertimbangan 
tersendiri bagi para pengambil kebijakan untuk memutuskannya.

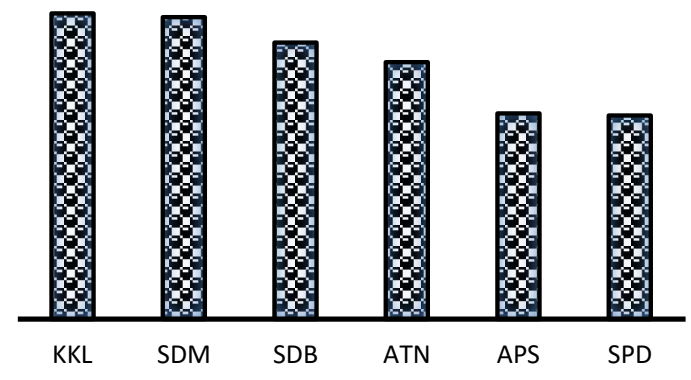

Gambar 5. Peringkat alternatif

Beberapa permasalahan yang mengemuka pada aspek Kondusifitas Kelembagaan antara lain adalah (1) hasil produksi rata-rata petani kopi yang terorganisir melalui koperasi lebih tinggi karena adanya dukungan agronomi dan teknologi, dibandingkan dengan petani yang tidak terorganisir (Almqvist, 2011), (2) petani dan kelompok tani selaku pelaku utama agroindustri menanggung beban risiko mutu paling besar dalam sistem rantai pasok kopi gayo (Jaya, 2014), (3) kelembagaan berperan penting sebagai media penyebaran inovasi hasil pertanian, sertifikasi dan pengelolaan mutu industri pangan seperti aplikasi teknologi alat pengeringan, pemanenan, pengangkutan dan pengemasan (Hennxsy, 2003; Budi et al., 2009, Silitonga; 2008, Putri et al., 2013; Walker, 2015), (4) pasar kopi di tingkat petani tidak terintegrasi dengan eksportir baik dalam jangka panjang maupun jangka pendek. Hal ini menunjukkan bahwa dalam proses penentuan harga petani cenderung sebagai penerima harga (Putri et al., 2013; Waroko et al., 2008; Yantu et al., 2010), (5) sinergisitas pelaku agroindustri kopi belum terbangun dengan baik terutama berkaitan dengan revenue sharing, spesifikasi mutu, jumlah dan time-delevery (Jaya, 2013; Putri et al., 2013).

Sementara pada aspek kualitas sumber daya manusia meliputi (1) pengembangan dan peningkatan sdm sangat tergantung pada penyuluh pertanian dengan fasilitas yang minim dan jumlah petugas yang terbatas berbanding wilayah perkebunan yang mesti ditangani (Jaya, 2013, Silitonga, 2008), (2) kurangnya pengembangan pemahaman dan manajemen pengetahuan dalam budidaya kopi, termasuk teknologi dan inovasi terkini, karena lebih mengandalkan pengetahuan secara turun temurun dari keluarga (Indra, 2011, Romano, 2009), (3) produktivitas belum optimal karena penguasaan teknologi yang kurang dan lemahnya ketrampilan petani (Bilhak dan Maarif, 2014, Ibrahim dan Zailani, 2010; Silitonga, 2008), (4) kurangnya kreatifitas dan inovasi dalam pengolahan produk dan industri pengolahan yang minim, terutama berkaitan dengan penanganan pasca panen dan pengolahan awal seperti fermentasi, pengolahan semi basah dan efisiensi penggunaan air (Fatma, 2011; Bilhak dan Maarif, 2014), (5) pendidikan dan pelatihan secara kontinyu terhadap petani kopi sangat diperlukan agar kualitas produksi menjadi lebih baik (Walker, 2015; Novita, 2012; Jaya, 2014; Mujiburrahman, 2011).

\section{Implikasi Manajerial}

hasil penelitian ini sangat membantu dalam pengambilan keputusan untuk pengembangan agroindustri kopi gayo di propinsi aceh. pertimbangan dalam pengambilan keputusan diperoleh bahwa kriteria kualitas produk yang dihasilkan menjadi kriteria yang paling utama menurut pendapat para pakar, dibandingkan kebijakan, standarisasi, konflik sosial dan gangguan keamanan. walaupun demikian berdasarkan pembobotan melalui metode fuzzy-eckenrode terlihat bahwa kriteria kebijakan dan gangguan keamanan menjadi kriteria berikutnya yang menjadi penting sebagai pertimbangan setelah kriteria kualitas produk.

Berdasarkan kelima kriteria yang dipertimbangkan melalui metode fuzzy-eckenrode, selanjutnya dilakukan penentuan alternatif prioritas pengembangan agroindustri kopi gayo melalui metode fuzzy-topsis. hasil yang diperoleh menunjukkan bahwa kondusifitas kelembagaan menjadi pertimbangan yang lebih utama dibandingkan alternatif lainnya. akan tetapi walaupun kondusifitas kelembagaan merupakan alternatif dengan rangking tertinggi, namun dalam penilaian pakar, alternatif pengembangan sumber daya manusia juga sangat terkait erat. ini bermakna bahwa dalam pengembangan agroindustri kopi gayo, selain kondusifitas kelembagaan yang menjadi pertimbangan utama, aspek sumber daya manusia juga menjadi urutan berikutnya yang memiliki koefisiensi kedekatan yang sangat erat dengan aspek kondusifitas kelembagaan.

\section{KESIMPULAN DAN SARAN.}

\section{Kesimpulan}

Sistem penunjang keputusan multi kriteria untuk pengembangan agroindustri kopi Gayo menggunakan pendekatan Fuzzy-Eckenrode mampu memberikan pembobotan secara baik untuk menentukan suatu kriteria tertentu, dan melalui pendekatan Fuzzy-Topsis dapat menemukan alternatif utama atau paling ideal dari sutau sistem pengembangan agroindustri kopi Gayo yang akan dilakukan. Berdasarkan pendekatan FuzzyEckenrode diperoleh penilaian bobot tertinggi adalah Kualitas dari berbagai aspek pembangunan agroindustri yang akan dilakukan, sedangkan dengan pendekatan Fuzzy-Topsis dapat diperoleh alternatif pengembangan agroindustri kopi Gayo yang harus lebih di utamakan adalah pada aspek kondusifitas kelembagaan (KKL). 
Saran

Penelitian ini masih terbatas pada ekplorasi permasalahan dalam pengembangan agroindustri kopi Gayo berdasarkan identifikasi dalam pembangunan suatu agroindustri. Penelitian lanjutan diperlukan untuk mengkaji secara komprehensif berbagai tindakan bagi pengembangan agroindustri kopi Gayo sehingga menjadi lebih baik lagi. Ditemukannya persoalan utama yang mengemuka berkaitan dengan aspek Kondusifitas Kelembagaan dan aspek Sumber Daya Manusia merupakan suatu petunjuk bagi penelitiansecara mendalam untuk menemukan langkah-langkah strategis yang diperlukan sebagai rekomendasi bagi para pengambil kebijakan.

\section{DAFTAR PUSTAKA}

[Disbun Aceh] Dinas Perkebunan Provinsi Aceh. 2013. Prospek Pengembangan Kopi Arabika Gayo di Kabupaten Aceh Tengah dan Bener Meriah. Aceh (ID): Disbun.

[Ditjenbun] Direktorat Jenderal Perkebunan. 2011. Statistik Perkebunan Indonesia 2010 - 2012. Kopi (Coffee). Jakarta, Desember 2011.

[Kementan] Kementerian Pertanian. 2013. Statistik Pertanian 2012 (Agricultural Statistics). Pusat Data dan Sistem Informasi Pertanian. Jakarta (ID): Kementan.

Almqvist AC. 2011. Coffee, a Fair Trade? -A Study about Fairtrade Certified Gayo Coffeee Farmers in Aceh, Indonesia. Department of Horticulture, Faculty of Landcape Planning, Horticulture and Agricultural Science, Swedish University of Agricultural Sciences (SLU)

Austin JE. 1992. Agroindustrial Project Analysis; Critical Design Factors. EDI Series in Economic Development. Baltimore and London: The Johns Hopkins University Press.

Bilhak A, dan Maarif S. 2014. Pengembangan Agribisnis Kopi dalam Kerangka Pembangunan Ekonomi Wilayah di Kabupaten Aceh Tengah. J Teknik PWK. 3 (2): 254-261.

Brown JG. 1994. Agroindustrial Investment and Operations. World Bank Institute (WBI) development study. EDI development studies. Washington DC: World Bank.

Budi LS, Maa'rif MS, Sailah I, Raharja S. 2009. Strategi Pemilihan Model Kelembagaan dan Kelayakan Finansial Agroindustri Wijen. J Tek Ind Pert. 19 (2): 56-63.

Dadelo S, Turskis Z, Zavadskas EK dan Dadeline R. 2012. Multiple Criteria Assessment of Elite Security Personal on the Basis of Aras and Expert Methods. J Eco Comp Eco Cybernet Studies Res. 46 (4): 65-88.

Dashti Z, Pedram MM, dan Shanbehzadeh J. 2010. A Fuzzy Multi-Criteria Decision Making
Based Sequence Ranking. Proceedings of International Multi-Conference of Engineers And Computer Scientists, Hong Kong.

Eckenrode RT. 1965. Weighting multiple criteria. Mgmt Sci. 12 (3): 180-192.

Fatma Z. 2011. Analisis Fungsi Produksi dan Efisiensi Usaha Tani Kopi Rakyat di Aceh Tengah. [Tesis]. Sekolah Pascasarjana IPB.

Hennexsy DA. 2003. Information Asymmetry as a Reason for Food Industry. Am $J$ Agric Econom. 74 (4): 167-176.

Herdyanti K. 2013. Perancangan Awal dan Analisis Kelayakan Usaha Pengolahan Biji Kopi di Kabupaten Bener Meriah Provinsi Aceh. Bogor (ID): Institut Pertanian Bogor.

Hulupi R, Nugroho D, dan Yusianto. 2013. Keragaan beberapa varietas lokal kopi arabika di dataran tinggi Gayo. Pelita Perkebunan. 29 (2): 69-81.

Ibrahim HW dan Zailani S. 2010. A review on the competitiveness of global supply chain in a coffee industry in Indonesia. Intl Bus Mgmt 4 (3): 105-115.

Indra. 2011. Penentuan skala usaha dan analisis efisiensi ekonomi usaha tani kopi rakyat di kabupaten Aceh Tengah. Agrisep 12 (1): 1-8.

Jaya R. 2014. Rancang Bangun Rantai Pasok Kopi Gayo Berkelanjutan. (Disertasi). Bogor (ID): Departemen Teknologi Industri Pertanian, Sekolah Pascasarjana IPB.

Jaya R. 2013. Model pengelolaan pasokan dan risiko mutu rantai pasok kopi Gayo. J Tek Ind Pert Indo. 5 (3): 24-32.

Maarif MS dan Tanjung H. 2003. Teknik-Teknik Kuantitatif untuk Manajemen. Jakarta: PT Gamedia Widiasarana Indonesia.

Mujiburrahman. 2011. Sistem jaringan pasok dan nilai tambah ekonomi kopi organik (Studi kasus di KBQ Baburrayan Kabupaten Aceh Tengah). Agrisep 12 (1): 1-10.

Nasution M. 2002. Pengembangan Kelembagaan Koperasi Pedesaan Untuk Agroindustri. Bogor: IPB Press.

Ningrum M, Sutarman, dan Sitepu R. 2010. Aplikasi metode topsis fuzzy dalam menentukan prioritas kawasan perumahan di kecamatan Percut Sei Tuan. Saintia Mat. 1 (1): 101-115.

Novita E. 2012. Desain proses pengolahan pada agroindustri kopi robusta menggunakan modifikasi teknologi olah basah berbasis produksi bersih. [Disertasi]. Bogor (ID): Institut Pertanian Bogor.

Putri MA. 2013. Sistem pemasaran kopi Arabika Gayo di Kabupaten Aceh Tengah dan Bener Meriah, Propinsi Aceh: Pendekatan structure, conduct, performance (SCP). [Thesis]. Bogor (ID): Program Studi Agribisnis, Sekolah Pascasarjana IPB. 
Romano. 2009. Kajian sistem agribisnis kopi organik di daerah pegunungan Gayo. J Apli Mjmn 7(1): 21-33.

Rouyendegh BD, dan Saputro TE. 2014. Supplier selection using integrated fuzzy TOPSIS and MCGP: A Case Study. Procedia - Social and Behavil Sci. 116: 3957-3970.

Salam AR. 2014. Analisis penentuan pelabuhan impor produk hortikultura: aplikasi metode eckenrode. Bul Ilmiah Litbang Perdag. 8 (1). $1-24$.

Salima R, Karim A, dan Sugianto. 2012. Evaluasi kriteria kesesuaian lahan kopi arabika Gayo 2 di dataran tinggi Gayo. J Mjmn Sumberdaya Lahan. 1 (2) : 194-206.

Saputra A. 2012. Desain rantai pasok kopi organik di Aceh tengah untuk optimalisasi balancing risk. [Tesis]. Bogor (ID): Institut Pertanian Bogor.
Silitonga CM. 2008. Analisis keunggulan bersaing kopi Arabika Gayo organik di Indonesia. [Tesis]. Medan (ID): Universitas Terbuka.

Walker H. 2015. Kopi, cooperatives \& compliance: a case study of fair trade in Aceh, Indonesia. [Thesis]. School of Geography, Environment \& Earth Scinece, Victoria University of Wellington.

Waroko TK, van Schalkwyk HD, Alemu ZG, Ayele G. 2008. Producer Price and Price Transmission in a Deregulated Ethiopian Coffee Market. Ag Econ. 47 (4). http://ageconsearch.umn.edu [24 Maret 2016].

Yantu MR, Bambang J, Hermanto S, Isang G, Setia H. 2010. Integrasi pasar kakao biji perdesaan Sulawesi Tengah dengan pasar dunia. J Agro Eko. 28 (2): 201-225. 